\title{
Pengaruh Penambahan Surfaktan pada Modifikasi Material Alam
}

\author{
Purbaningtias, TE ${ }^{*}$; Kurniawati, P; Wiyantoko, B ${ }^{1}$; Prasetyoko, D; Suprapto ${ }^{2}$ \\ ${ }^{+}$Diploma III Analisis Kimia, Universitas Islam Indonesia, UII. Kampus Terpadu UII JI. Kaliurang Km 14.5 Yogyakarta \\ ${ }^{2}$ Departemen Kimia, Insitut Teknologi Sepuluh Nopembet, ITS. Kampus ITS Sukolilo, Suarabaya
}

\begin{abstract}
Purple cabbage has distinctive color which is purple due to anthocyanin. Anthocyanin is natural pigmen that has high sensitivity in color change every level of $\mathrm{pH}$ changes acid to base. The anthocyanin sensitivity can be used color indicator. The purpose of this research is utilization purple cabbage extract as color indicator hydroquinone analysis. The research method in this research is maceration extract by executing optimizations such as temperatur optimization and optimization of maceration time. Based on the results of the research has obtained regression equation $\mathrm{y}=0,001 \mathrm{x}+0,0574$ with a value or $\mathrm{R}=0,947$. It can be concluded that purple cabbage extract can be used as color indacator on hydroquinone analysis
\end{abstract}

Keywords: natural zeolite, rice husk, raw bagasse, surfactant, mesopore modified.

\begin{abstract}
Abstrak
Penelitian ini berkaitan dengan pengembangan bahan alam dari zeolit alam, sekam padi dan ampas tebu. Modifikasi bahan alam dilakukan dengan menggunakan cetyltrimethyllammonium bromide (CTAB) sebagai surfaktan kationik untuk templat mesopori. Karakter fisikokimia bahan alam yang termodifikasi dan tanpa modifikasi diselidiki dengan menggunakan XRF, XRD, FTIR, fisisorpsi nitrogen, dan SEM-EDX. Kandungan utama dari bahan alam adalah Silika (Si) yang dibuktikan dari analisis XRF. Analisis XRD menunjukkan bahwa modifikasi dengan penambahan surfaktan dapat menyebabkan penurunan kristalinitas zeolit alam dan ampas tebu, sedangkan kristalinitas sekam padi meningkat. Munculnya pita serapan spesifik pada hasil karakterisasi menggunakan FTIR menunjukkan adanya gugus silanol dan siloksan pada semua material yang membuktikan bahwa semua jenis material alam tersebut merupakan material ekonomis yang kaya akan silika. Sementara itu profil fisisorpsi nitrogen memberikan informasi bahwa modifikasi pori oleh surfaktan hanya berhasil pada ampas tebu. Morfologi bahan alam yang dimodifikasi dan tidak dimodifikasi serta komposisi kimia dari partikel ditunjukkan oleh SEM-EDX.
\end{abstract}

Keyword: Zeolite alam, sekam padi, ampas tebu, surfaktan, modifikasi mesopori. 


\section{Pendahuluan}

Material alam banyak dimanfaatkan sebagai adsorben karena cukup mudah ditemukan dan harganya cukup murah. Pemanfaatan material alam yang sering digunakan sebagai adsorben alam adalah zeolit alam, sekam padi dan ampas tebu. Untuk meningkatkan daya dan efektivitas adsorpsi dari adsorben alam dilakukan modifikasi berupa sistem mesopori. Material mesopori akan memiliki luas permukaan yang lebih besar dibandingkan dengan luas permukaan adsorben alam yang belum dimodifikasi, sehingga kontak binding site pada adsoerben dan adsorbat akan semakin luas. Material berpori dapat dibagi menjadi 3 kategori berdasarkan ukuran pori, yaitu, material mikropori dengan ukuran pori-pori kurang dari $2 \mathrm{~nm}$, mesopori dengan ukuran pori antara 2 hingga $50 \mathrm{~nm}$, dan makropori dengan ukuran pori lebih dari $50 \mathrm{~nm}$ [1]. Contoh material porous seperti clay, alumina anodik, karbon nanotubes dan yang berhubungan dengan karbon porous lainnya. Diantara semua material mikropori, zeolit dikenal yang terbaik, karena mempunyai distribusi ukuran mikropori yang seragam dan sempit pada sistem pori-porinya [2]. Molekul mesopori memiliki pori-pori yang cukup besar, sehingga dapat digunakan untuk cetakan pada sintesis polimer dan senyawa yang berukuran besar lainnya serta menghasilkan dispersi partikel yang lebih baik [3].

Lee et al. [4] melakukan sintesis material mesopori dari zeolit konvensional menggunakan surfaktan kationik cetyltrimethylammonium bromide (CTAB) sebagai bahan pengarah mesostruktur. Skema proses sintesis dapat dilihat pada Gambar 1. Pada langkah awal kandungan logam Si dan Al dalam zeolit konvensional didekonstruksi menjadi nano material dengan cara melarutkannya dalam larutan $\mathrm{NaOH}$. Selanjutnya kandungan logam tersebut dikonstruksi ulang dengan cara pembentukan ulang menggunakan CTAB sebagai pengarahnya. Langkah terakhir adalah kalsinasi, pada proses ini CTAB akan terdekomposisi dan hilang dari material sehingga akan terbentuk pori meso pada material tersebut [4]. Pada penelitian ini akan dilihat pengaruh penambahan surfaktan, CTAB, terhadap struktur dan permukaan material alam yaitu zeolite alam, ampas tebu dan sekam padi..

\section{Metode Penelitian}

\section{Sintesis Abu Sekam Padi}

Sekam padi yang diperoleh dari petani yang ada di daerah Prambanan, Yogyakarta, dibersihkan dan dicuci bersih dengan air distilasi dan dikeringkan menggunakan oven 
dengan suhu $70 \circ \mathrm{C}$ selama 24 jam. Ampas sekam padi yang sudah kering kemudian difurnace pada temperatur $750 \mathrm{oC}$ selama 4 jam.

\section{Sintesis Abu Ampas Tebu}

Ampas tebu yang berasal dari PG Madukismo, Bantul, Yogyakarta, dibersihkan dan dicuci bersih dengan air distilasi dan dikeringkan menggunakan oven dengan suhu $70 \mathrm{oC}$ selama 24 jam. Ampas tebu yang sudah kering kemudian dikalsinasi pada temperatur 750 oC selama 4 jam.

\section{Sintesis Material Mesopori (MM)}

Material mesopori disintesis sesuai metode penelitian yang dilakukan oleh Lee et al. [4](2008). Adsorben alam dilarutkan dengan larutan $\mathrm{NaOH}$. Komposisi rasio molar $\mathrm{NaOH}$ dan jumlah logam pada adsorben alam $(\mathrm{NaOH} / \square \operatorname{logam})$ adalah $0,5-$ 4,0. Larutan $\mathrm{NaOH}$ dibuat dengan melarutkan $1,5 \mathrm{~g} \mathrm{NaOH}$ dalam $5 \mathrm{~g}$ akuades.
Campuran adsorben alam dan $\mathrm{NaOH}$ diaduk hingga terbentuk larutan yang jernih, setelah itu ditambahkan dengan 2,5 g akuades. Larutan ini merupakan larutan sumber kerangka material mesopori (MM). Selanjutnya dibuat larutan CTAB dengan cara 4,6 g CTAB dilarutkan dalam $70 \mathrm{~g}$ akuades. Larutan sumber kerangka ditambahkan ke dalam larutan CTAB setetes demi setetes dengan diaduk secara terus menerus, setelah itu larutan diaduk selama 24 jam pada temperatur ruang. Selanjutnya campuran dipanaskan pada $373 \mathrm{~K}$ selama 24 jam. Endapan yang terbentuk disaring dan dicuci dengan akuades serta dikeringkan pada 373 K semalaman. Setelah itu padatan yang terbentuk dicuci dengan campuran $\mathrm{HCl} /$ etanol dan dikalsinasi pada $823 \mathrm{~K}$ selama 3 jam untuk menghilangkan surfaktan CTAB.

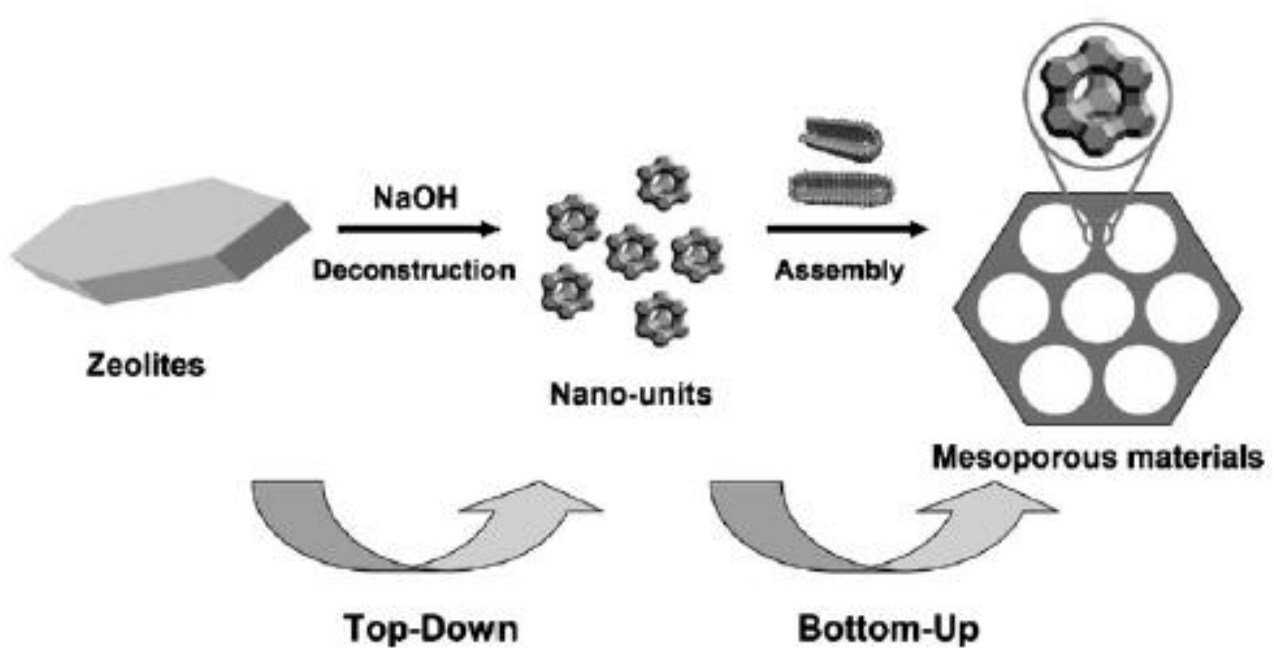

Gambar 1 Skema sintesis material mesopori dari zeolit konvensional [4]. 


\section{Hasil dan Pembahasan}

\section{X-Ray Fluorescence (XRF)}

Karakterisasi XRF merupakan karakterisasi semi kuantitatif yang merupakan karakterisasi komposisi logam awal pada material. Hasil analisis XRF dari material zeolit alam, ampas tebu dan sekam padi ditunjukkan pada Tabel 1. Berdasarkan Tabel 1 bahwa kandungan senyawa yang paling tinggi dari ketiga material alam adalah silika. Jumlah silika paling banyak terdapat dalam material sekam padi. Data pada Tabel 1 juga menunjukkan masih adanya banyak pengotor logam lainnya seperti besi, seng, nikel dan titanium. Pengotor-pengotor logam sangat tidak bagus untuk proses adsorpsi minyak nilam karena akan menyumbangkan konsentrasi logam dalam komposisi minyak nilam. Oleh karena itu perlu adanya proses penghilangan pengotor pada material alam zeolit alam, ampas tebu dan sekam padi dengan proses leaching. Proses leaching pada material kaya silika dapat dilakukan dengan proses refluks menggunakan larutan $\mathrm{HCl}$ [5]. Ugheoke dan Mamat [6] menyatakan bahwa efisiensi $\mathrm{HCl}>\mathrm{H}_{2} \mathrm{SO}_{4}>\mathrm{HNO}_{3}$ dalam proses leaching. Oleh karena itu pada penelitian ini dilakukan proses leaching menggunakan $\mathrm{HCl}$ dengan metode refluks.

\section{X-Ray Diffraction (XRD)}

Karakterisasi menggunakan XRD merupakan teknik analisis untuk mengetahui tingkat kristalinitas serta identifikasi jenis kristal penyusun zeolit alam, sekam padi, ampas tebu serta material mesoporinya.

Tabel 1 Hasil Analisis XRF

\begin{tabular}{|l|l|c|c|c|}
\hline \multirow{2}{*}{ No. } & \multirow{2}{*}{ Komposisi } & Zeolit Alam & $\begin{array}{c}\text { Ampas } \\
\text { Tebu }\end{array}$ & Sekam Padi \\
\cline { 3 - 5 } & & 51,9 & 38,5 & 78,0 \\
\hline 1 & $\mathrm{SiO}_{2}$ & 5,11 & 18,4 & 11,3 \\
\hline 2 & $\mathrm{~K}_{2} \mathrm{O}$ & - & - & 2,2 \\
\hline 3 & $\mathrm{P}_{2} \mathrm{O}_{5}$ & 15,8 & 20,5 & 4,19 \\
\hline 4 & $\mathrm{CaO}$ & - & 1,5 & - \\
\hline 5 & $\mathrm{SO}_{3}$ & 7,7 & - & - \\
\hline 6 & $\mathrm{Al}_{2} \mathrm{O}_{3}$ & 13,1 & 12,3 & 0,72 \\
\hline 7 & $\mathrm{Fe}_{2} \mathrm{O}_{3}$ & 0,096 & 0,70 & 1,2 \\
\hline 8 & $\mathrm{MnO}$ & 0,08 & 0,64 & 0,074 \\
\hline 9 & $\mathrm{ZnO}$ & 2,2 & 1,29 & 1,38 \\
\hline 10 & $\mathrm{NiO}$ & 1,72 & 0,54 & 0,19 \\
\hline 11 & $\mathrm{TiO}$ & & & \\
\hline
\end{tabular}




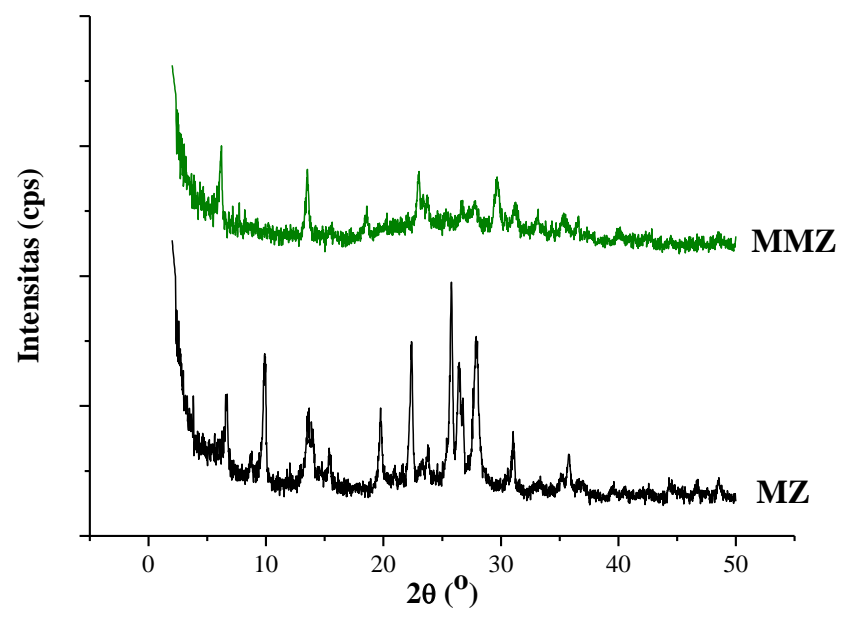

\section{Gambar 2 Difraktogram Zeolit Alam (MZ) dan Zeolit Alam Termodifikasi CTAB (MMZ)}

Gambar 2 adalah pola difraksi sinar-X zeolit alam dan material mesopori zeolit. Difraksi sinar-X digunakan untuk menunjukkan kristalinitas struktur dari zeolit alam dan material mesopori zeolit. Spektrum difraksi menunjukkan beberapa puncak tajam dengan intensitas tinggi pada difraktogram zeolit alam. Puncak yang memiliki intensitas tinggi pada $2 \theta=10^{\circ}, 15^{\circ}, 20^{\circ}-30^{\circ}$ merupakan komponen-komponen penyusun zeolit alam. Seperti terlihat pada difraktogram bahwa zeolit alam tersebut memiliki kristalinitas yang tinggi. Sementara pola difraksi material mesopori zeolit menunjukkan adanya penurunan intensitas pada puncak-puncak karakteristik komponen penyusunnya. Namun puncak-puncak tersebut masih memiliki tingkat kristalinitas yang baik.

Gambar 3 adalah pola difraksi sinar-X abu sekam padi dan material mesopori sekam padi. Difraksi sinar-X digunakan untuk menunjukkan kristalinitas struktur dari sekam padi dan material mesopori sekam padi. Spektrum difraksi dengan intensitas rendah pada $2 \theta=10^{\circ}-20^{\circ}$ merupakan kompoenen penyusun sekam padi. Puncak difraksi yang melebar di sekitar $2 \theta=15^{\circ}-30^{\circ}$ mengindikasikan sifat alami silika amorf sebagai komponenen utama sekam padi. Sementara pola difraksi material mesopori sekam padi menunjukkan refleksi khas pada daerah sudut $2 \theta=20^{\circ}-30^{\circ}$. Pola refleksi ini 
khas untuk silika heksagonal dengan struktur mesopori seragam.

Gambar 4 adalah pola difraksi sinar$\mathrm{X}$ ampas tebu dan material mesopori ampas tebu. Difraksi sinar-X digunakan untuk menunjukkan kristalinitas struktur dari ampas tebu dan material mesopori ampas tebu. Spektrum difraksi dengan intensitas tinggi pada $2 \theta=22^{\circ}$ merupakan keberadaan selulosa seperti yang dilaporkan oleh Utomo et al. [7]. Puncak difraksi melebar di sekitar $2 \theta=18^{\circ}$ dan $30^{\circ}$ mengindikasikan sifat alami silika amorf sebagai komponenen utama ampas tebu. Hasil yang sama telah dilaporkan oleh Govindarajan dan Jayalakshmi [8] serta Worothanakul et al [9]. Sementara pola difraksi material mesopori ampas tebu menunjukkan refleksi khas pada daerah sudut rendah $2 \theta=2^{\circ}$. Pola refleksi khas material mesopori mewakili bidang (100), (110), (200), dan (210) hanya terlihat pada daerah sudut rendah $2 \theta=2^{\circ}-5^{\circ}$. Hasil ini telah dikonfirmasi oleh Shaikh dan Shaikh [10]. Pola refleksi ini khas untuk silika heksagonal dengan struktur mesopori seragam.

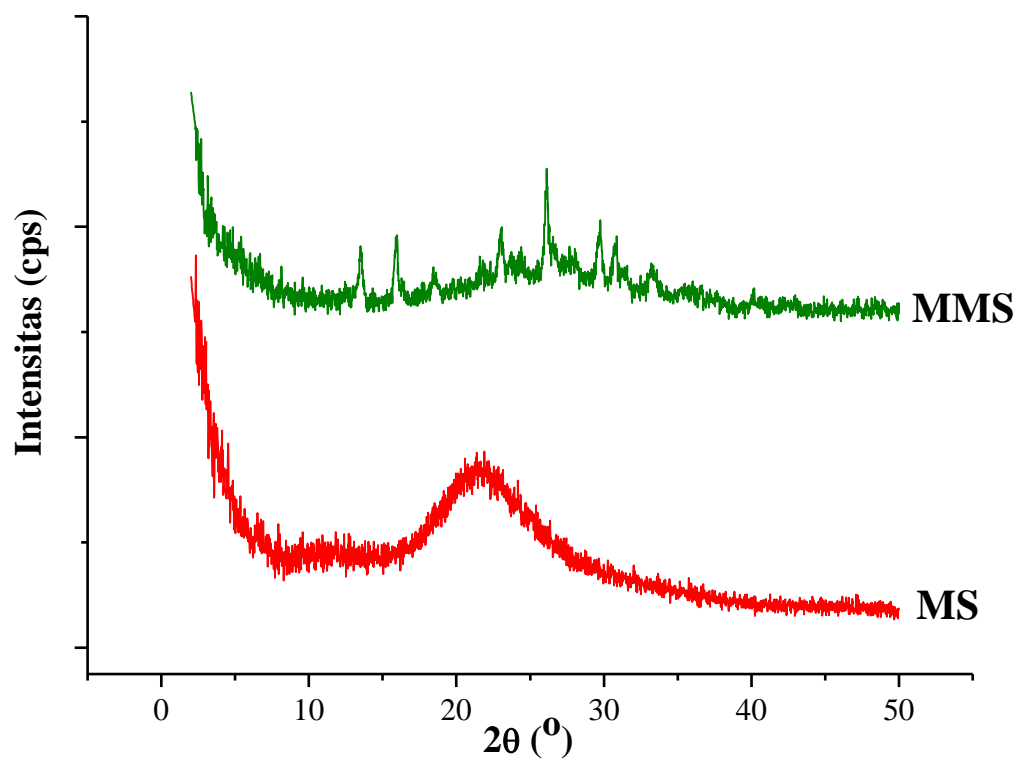

Gambar 3 Difraktogram Sekam Padi (MS) dan Sekam Padi Termodifikasi CTAB (MMS) 


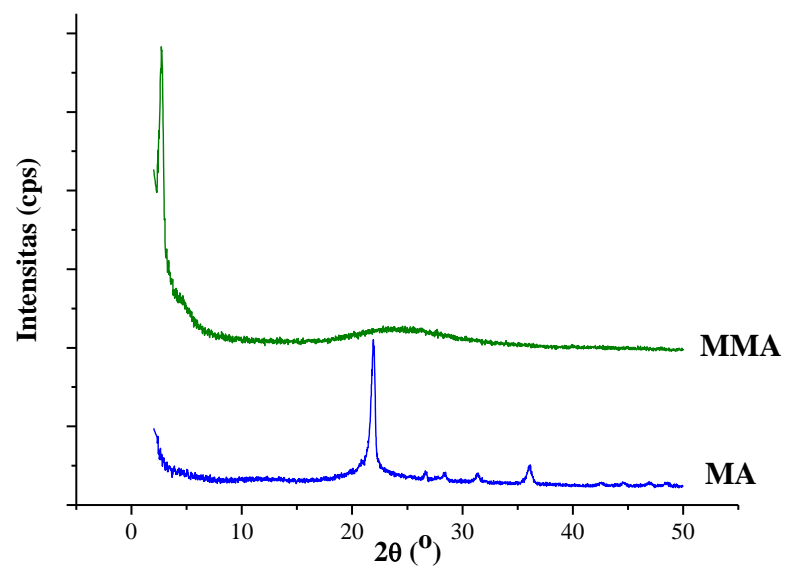

Gambar 4 Difraktogram Ampas Tebu (MA) dan Ampas Tebu Termodifikasi CTAB (MMA)

Spektrofotometer Fourier Transform Infra Red (FTIR)

\begin{abstract}
Karakterisasi FTIR dilakukan untuk mengidentifikasi adanya gugus fungsi penyusunnya dan adanya pengotor dalam material. Material yang dianalisis adalah material alam yang telah mengalami proses leaching yaitu zeolit alam (MZ), abu ampas tebu (MA) dan abu sekam padi (MS) dan material alam yang telah dimodifikasi CTAB yaitu zeolit alam mesopori (MMZ), ampas tebu mesopori (MMA) dan sekam padi mesopori (MMS). Hasil karakterisasi FTIR dengan daerah bilangan gelombang 4000 $400 \mathrm{~cm}^{-1}$ pada ketiga material alam yang digunakan dapat dilihat pada Gambar 5 dan Tabel 2.
\end{abstract}

Gambar 5 menunjukkan kemiripan gugus fungsi dalam struktur zeolit, ampas tebu dan sekam padi baik sebelum modifikasi maupun sesudah modifikasi. Perbedaan yang terlihat antara material alam yang dimodifikasi dengan CTAB dan tanpa modifikasi adalah perubahan intensitas puncak. Pada material sekam padi, adanya modifikasi menyebabkan puncak pada bilangan gelombang 1046,62 $\mathrm{cm}^{-1}$. Berbeda halnya dengan yang terjadi pada material ampas tebu dan zeolit, adanya modifikasi menyebabkan intensitas puncak yang semakin besar. Hal ini mengindikasikan bahwa modifikasi dengan CTAB dapat mempengaruhi jumlah Si dan Al. Spektra IR pada Gambar 5 dan Tabel 2 juga menunjukkan pita serapan spesifik untuk gugus fungsi hidroksil stretching, hidroksil bending, silanol dan siloksan. Munculnya puncak melebar pada daerah bilangan 
gelombang $3400-3500 \mathrm{~cm}^{-1}$ menunjukkan adanya gugus hidroksil $(-\mathrm{OH})$ stretching dari gugus silanol dan molekul kristal $\mathrm{H}_{2} \mathrm{O}$ yang teradsorp di permukaan material. Keadaan tersebut diperkuat dengan munculnya pita serapan pada 1635 - 1641 $\mathrm{cm}^{-1}$ yang menunjukkan adanya vibrasi - $\mathrm{OH}$ bending dari molekul $\mathrm{H}_{2} \mathrm{O}$. Keenam material menunjukkan adanya serapan vibrasi jembatan $\mathrm{O}-\mathrm{Si}-\mathrm{O}$ symmetric dan asymmetric pada daerah $1046-1099 \mathrm{~cm}^{-1}$. Dengan munculnya pita serapan di sekitar $3400 \mathrm{~cm}^{-1}$ dan $1100 \mathrm{~cm}^{-1}$ membuktikan adanya vibrasi streching gugus $\mathrm{Si}-\mathrm{O}-\mathrm{H}$ dari gugus silanol ataupun ikatan molekul
$\mathrm{H}_{2} \mathrm{O}$ di permukaannya. Pita serapan pada daerah sekitar $1100 \mathrm{~cm}^{-1}$ juga menunjukkan gugus $\mathrm{Al}-\mathrm{O}$ pada struktur $\mathrm{TO}_{4}$ (tetrahedral). Muncul pita serapan pada ampas tebu dan sekam padi pada bilangan gelombang 800 $\mathrm{cm}^{-1}$ yang menunjukkan adanya vibrasi symmetric $\mathrm{Si}-\mathrm{O}-\mathrm{H}$. Akan tetapi, peak ini tidak muncul pada hasil karakterisasi zeolit alam, sehingga munculnya pita serapan pada $1100 \mathrm{~cm}^{-1}$ menunjukkan adanya interaksi antara molekul $\mathrm{H}_{2} \mathrm{O}$ di permukaan material dan membentuk ikatan $\mathrm{Si}-\mathrm{O}-\mathrm{H}$. Adanya gugus siloksan $(\mathrm{Si}-\mathrm{O})$ ditunjukkan dengan munculnya pita serapan pada bilangan gelombang $448-467 \mathrm{~cm}^{-1}$.

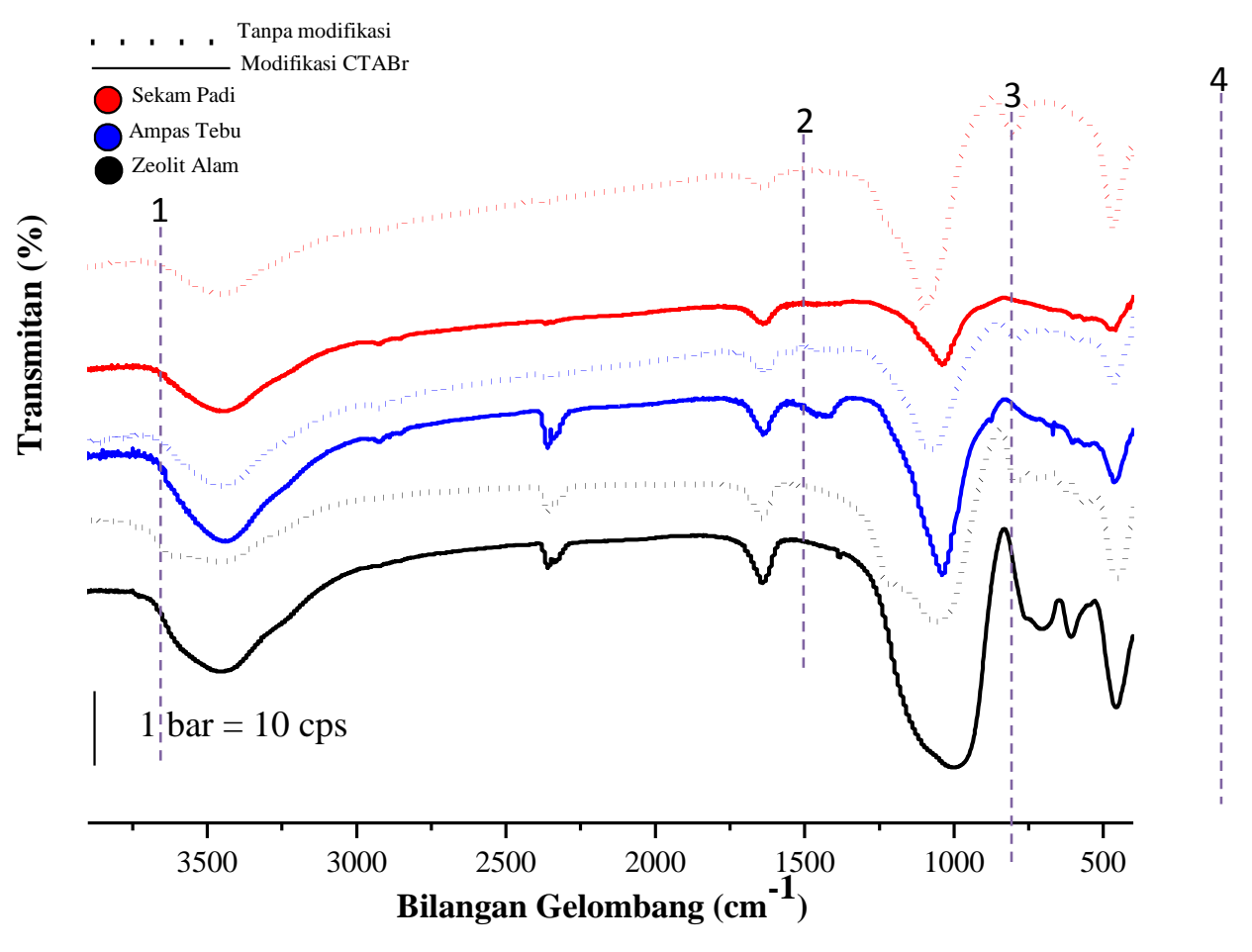

Gambar 5 Spektra FTIR Material Alam dan Material Alam Termodifikiasi CTAB 
Tabel 2 Hasil Analisis Gugus Fungsional

\begin{tabular}{|c|c|c|c|c|}
\hline \multirow{2}{*}{ No. } & \multicolumn{3}{|c|}{ Bilangan Gelombang $\left(\mathbf{c m}^{-1}\right)$} & \multirow{2}{*}{ Keterangan } \\
\cline { 2 - 4 } & Zeolit Alam & $\begin{array}{c}\text { Ampas } \\
\text { Tebu }\end{array}$ & Sekam Padi & Hidroksil stretching \\
\hline 1 & 3437,46 & 3451,2 & 3455,6 & Hidroksil bending \\
\hline 2 & 1641,15 & 1639,93 & 1635,97 & Si - O symmetric dan asymmetric \\
\hline 3 & 1046,62 & 1071,65 & 1099,92 & Silanol stretching \\
\hline 4 & - & 792,58 & 800,68 & Siloksan bending \\
\hline 5 & 448,57 & 464,37 & 467,35 & \\
\hline
\end{tabular}

Munculnya pita serapan spesifik pada hasil karakterisasi menggunakan FTIR menunjukkan adanya gugus silanol dan siloksan pada ketiga jenis material. Hal tersebut membuktikan bahwa semua jenis material alam tersebut merupakan material ekonomis yang kaya akan silika. Hasil karakterisasi FTIR tersebut juga linear dengan penelitian Ibrahim et al. [11], Mahamed et al. [12], Suyanta dan Kuncaka [5], Govindarajan dan Jayalakhsmi [8], serta Moises et al. [13].

\section{Adsorpsi-Desorpsi Nitrogen}

Penentuan distribusi pori dan total luas permukaan suatu padatan dapat dilakukan dengan berdasarkan prinsip adsorpsi fisik (fisisorpsi) nitrogen dengan permukaan padatan [14]. Gambar 6 merupakan isoterm adsorpsi-desorpsi $\mathrm{N}_{2}$ dari material alam tanpa modifikasi (MZ, MS, dan MA) dan material alam dengan modifikasi pori (MMZ, MMS, dan MMA) serta distribusi pori dari tiap-tiap material (gambar inset). Pola isoterm adsorpsi-desorpsi material MZ, MS dan MMA memperlihatkan adanya perbedaan jumlah nitrogen antara proses adsorpsi dan desorpsi yang membentuk hysteresis loop pada daerah pertengahan $\mathrm{P} / \mathrm{P}_{0}$ menunjukkan tipe isoterm adsorpsi-desorpsi tipe IV yaitu jenis adsorpsi dari padatan mesopori dengan ukuran diameter pori 2-50 nm [15]. Hysteresis loop ini diakibatkan terjadinya kondensasi kapiler akibat adanya pori pada permukaan padatan [16]. Hysteresis loop yang terjadi pada tekanan relatif antara 0,55 sampai 0,8 , menunjukkan adanya pola distribusi ukuran diameter pori dengan rentang 3-6 nm [17]. Sedangkan pada sampel MMZ, MMS, dan MA tidak terlihat adanya loop histerisis yang berarti bahwa material tersebut tidak termasuk material mesopori. Dari ketiga jenis material alam yang dimodifikasi pori dengan CTAB hanya material ampas tebu (MMA) yang menunjukkan keberhasilan pembentukan pori 
meso. Hasil ini sesuai dengan indikasi yang didapat dari analisis XRD. Pada analisis XRD puncak pada $2 \theta<5$ menunjukkan indikasi mesopori material. Pada sampel zeolit alam dan sekam padi, adanya penambahan CTAB mengakibatnya puncaknya menurun yang berarti bahwa modifikasi menyebabkan hilangnya pori meso, sedangkan pada material ampas tebu terjadi kebalikannya, adanya penambahan CTAB menyebabkan puncak semakin tinggi yang berarti pori meso dalam maetrial modifikasi bertambah.

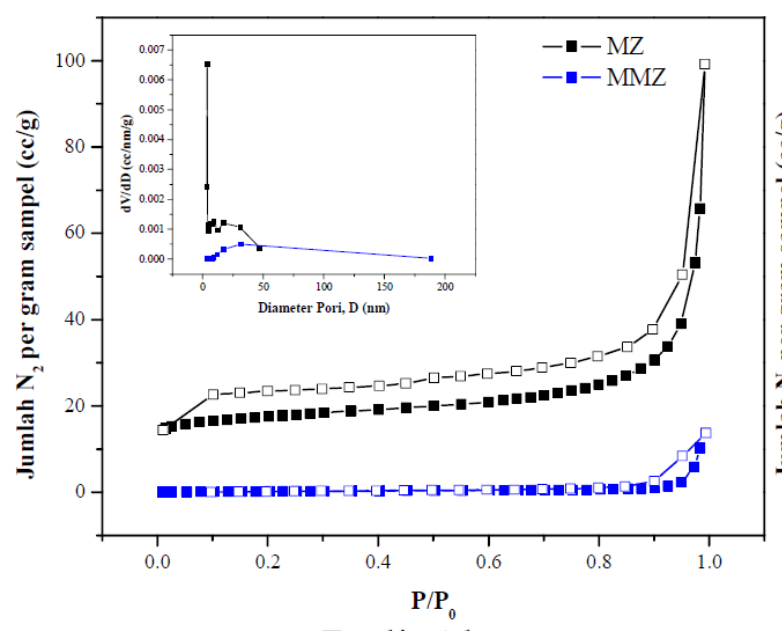

Zeolit Alam

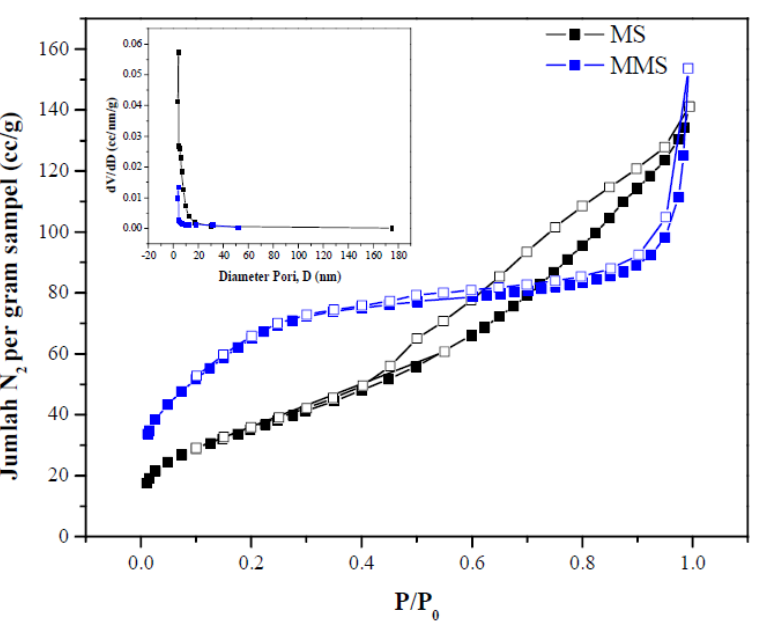

Sekam Padi

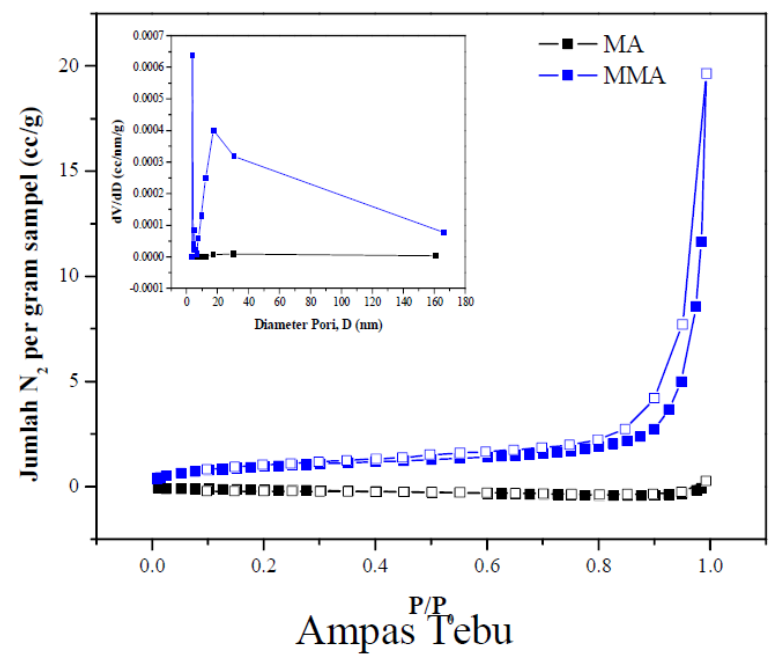

Gambar 6 Isoterm adsorpsi-desorpasi $\mathbf{N}_{\mathbf{2}}$ dari material alam tanpa dan dengan modifikasi serta distribusi pori dari tiap-tiap material (gambar inset). Adsorpsi (tertutup, -), desorpsi (terbuka, ㅁ). 
Pembuktian terhadap adanya mesopori pada permukaan sampel dapat dilihat dari data distribusi ukuran pori berdasarkan analisis Barret, Joiner, Halenda (BJH) pada gambar inset dalam Gambar 6. Berdasarkan gambar inset, dapat disimpulkan bahwa adanya histeresis pada sampel padatan MZ, MS, dan MMA disebabkan adanya mesopori. Hal ini juga ditunjukkan dengan adanya puncak pada diameter pori lebih dari $2 \mathrm{~nm}$ (sekitar 3-4 nm) dalam grafik distribusi ukuran pori. Berdasarkan puncak yang tinggi pada daerah diameter pori 3-4 nm, dapat disimpulkan bahwa ukuran diameter pori yang paling dominan adalah 3-4 $\mathrm{nm}$. Selain itu, pada Gambar 6 (gambar inset) juga menunjukkan bahwa pada sampel MS hanya memiliki satu puncak yang berarti bahwa material MS hanya memiliki satu ukuran dimaeter pori yang dominan yaitu 3,84 $\mathrm{nm}$. Sama halnya dengan MS, padatan MZ memiliki satu puncak utama yang menunjukkan satu ukuran dominan yaitu 3,84 $\mathrm{nm}$, tetapi terdapat satu puncak lagi yan berukuran lebih kecil yang menunjukkan jumlah pori berukuran 17,33 nm yang sedikit. Sedangkan pada material MMA, puncaknya lebih beragam yaitu pada diameter pori 3,82 ; 4,90; dan 17,36 nm. Ukuran diameter pori yang paling banyak terdapat pada MMA adalah 3,82 nm karena memiliki puncak yang paling tinggi. Pada analisis data berdasarkan Brunauer, Emmet, dan Teller (BET) dapat diketahui luas permukaan material yaitu $55,697 \mathrm{~m}^{2} / \mathrm{g}$ untuk MZ; 0,835 $\mathrm{m}^{2} / \mathrm{g}$ untuk MMZ; 130,652 $\mathrm{m}^{2} / \mathrm{g}$ untuk MS; 233,452 $\mathrm{m}^{2} / \mathrm{g}$ untuk MMS, $0 \mathrm{~m}^{2} / \mathrm{g}$ untuk MA dan $3,438 \mathrm{~m}^{2} / \mathrm{g}$ untuk MMA. Modifikasi pori dengan penambahan CTAB menyebabkan perbedaan luas permukaan, pada zeolit alam, adanya modifikasi menyebabkan luas area menurun sedangkan untuk sekam padi dan ampas tebu, modifikasi dapat meningkatkan luas permukaannya.

Scanning Electron Microscopy with Energy Dispersive X-Ray Analysis (SEM-EDX)

Analisis SEM dilakukan untuk mengetahui morfologi material alam. Gambar 7 menunjukkan morfologi material alam sebelum dan sesudah modifikasi CTAB dengan perbesaran 5000 kali. Pada Gambar 7 dapat dilihat pengaruh modifikasi menggunakan $\quad$ CTAB pada penampakan/morfologi dari material alam. Pada material sekam padi dan ampas tebu, adanya proses modifikasi dengan CTAB membuat partikel padatan menjadi lebih kecil dan terpisah, tidak lagi dalam bentuk lembaran. Sedangkan pada zeolit alam, adanya modifikasi CTAB menyebabkan bergabungnya partikel-partikel padatan yang 
kecil menjadi sebuah padatan yang lebih besar.

Komposisi elemen pada permukaan sampel ditentukan dengan EDX. Hasil analisis unsur sampel hidrotalsit dapat dilihat pada Tabel 3. Hasil analisis EDX ini mendukung data FTIR. Perubahan intensitas spektra menunjukkan bahwa jumlah Si dan
Al berbeda. Pada material alam sekam padi terjadi penurunan jumlah $\mathrm{Si}$ dan $\mathrm{Al}$ akibat adanya perlakuan modifikasi dengan CTAB. Sedangkan pada material zeolit alam dan ampas tebu adanya modifikasi CTAB menyebabkan terjadinya kenaikan jumlah $\mathrm{Si}$ dan $\mathrm{Al}$

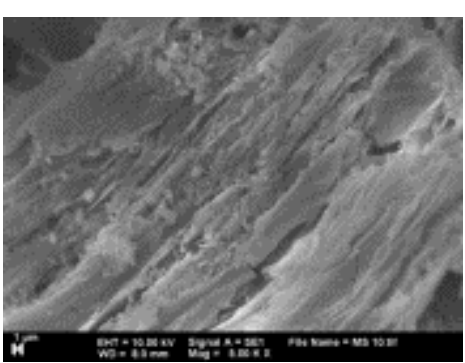

A

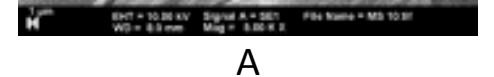

Sekam Padi

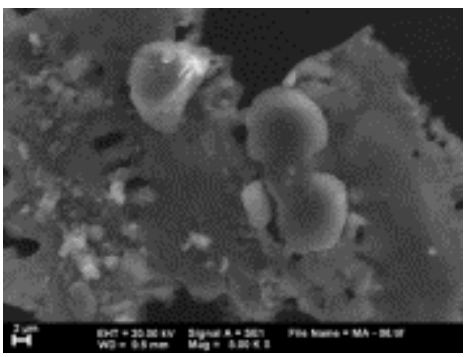

A

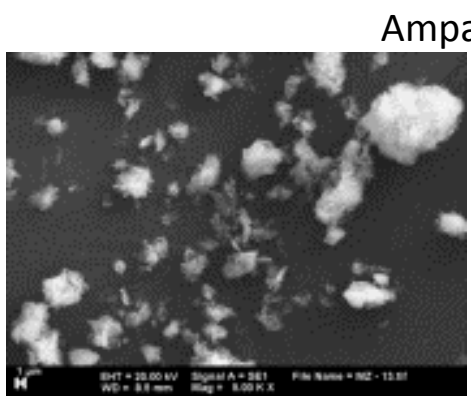

A

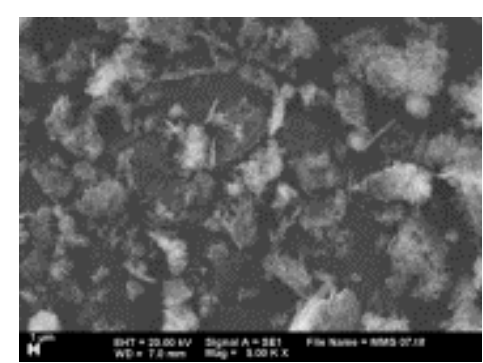

B

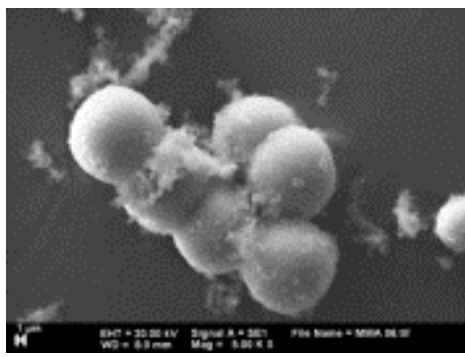

B

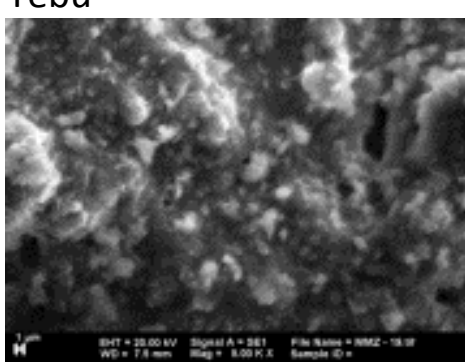

B

Zeolit Alam

Gambar 7 Morfologi SEM Material Alam Sekam Padi, Ampas Tebu dan Zeolit Alam dengan Perbesaran 5000 kali (a) Tanpa Modifikasi (b) Modifikasi CTAB 
Tabel 3 Analisis Elemen EDX dari Material Alam

\begin{tabular}{|c|c|c|c|c|c|}
\hline \multirow{2}{*}{$\begin{array}{c}\text { Material } \\
\text { Alam }\end{array}$} & \multicolumn{3}{|c|}{ Elemen $(\mathbf{\%} \mathbf{W t})$} & Jumlah Si dan Al & \multirow{2}{*}{ Rasio Si/Al } \\
\cline { 2 - 4 }$(\mathbf{\%} \mathbf{~ W t})$ & $\mathrm{O}$ & $\mathrm{Si}$ & $\mathrm{Al}$ & 30,27 & 3,03 \\
\hline MS & 69,70 & 30,26 & 0,01 & 10,35 & 10,25 \\
\hline MMS & 88,19 & 9,43 & 0,92 & 18,75 & 124 \\
\hline MA & 80,06 & 18,60 & 0,15 & 33,02 & 2,08 \\
\hline MMA & 55,65 & 22,29 & 10,73 & 7,04 & 3 \\
\hline MZ & 91,34 & 5,28 & 1,76 & 8,32 & 2,59 \\
\hline MMZ & 65,00 & 6,00 & 2,32 & & \\
\hline
\end{tabular}

\section{Kesimpulan}

paling banyak terdapat dalam material sekam padi. Terdapat perbedaan kristalinitas pada material alam setelah termodifikasi surfaktan (CTAB), kristalinitas dari zeolit alam dan ampas tebu mengalami penurunan setelah penambahan surfaktan sedangkan pada sekam padi justru terjadi kebalikannya, kristalinitas material semakin bertambah dengan adanya pengaruh perlakuan surfaktan. Adanya penambahan perlakuan dengan CTAB tidak menyebabkan perbedaan pada puncak yang muncul dalam spektra FTIR. Perbedaan yang terjadi adalah perubahan intensitas puncak pada bilangan gelombang $1046,62 \mathrm{~cm}^{-1}$. Proses modifikasi pori adsorben alam dengan CTAB hanya meningkatkan jumlah distribusi diameter pori 3-4 nm pada ampas tebu, sedangkan pada zeolit alam dan sekam padi terjadi penurunan distribusi ukuran pori.

\section{Ucapan Terimakasih}

Penelitian ini didanai oleh Kementerian Riset, Teknologi dan Pendidikan Tinggi melalui Hibah Penelitian Kerjasama Antar Perguruan Tinggi (PEKERTI) antara Universitas Islam Indonesia dan Institut Teknologi Sepuluh Nopember Surabaya Tahun 2015-2016.

\section{Daftar Pustaka}

[1] K. S. W. Sing, D. H. Everett, R. A. W. Haul, L. Moscou, R. A. Pierotti, J. Rouquerol, T. Siemieniewska, "Reporting physisorption data for gas/solid systems with special reference to the determination of surface area and porosity (Recommendations 1984)," Pure Appl. Chem., vol. 57, no. 4, pp. 603-619, 2007.

[2] J. Wang, W. Yue, W. Zhou, and M. O. Coppens, "TUD-C: A tunable, hierarchically structured mesoporous 
zeolite composite," Microporous Mesoporous Mater., vol. 120, no. 1-2, pp. 19-28, 2009.

[3] Y. Zhang, K. J. Balkus, I. H. Musselman, and J. P. Ferraris, "Mixedmatrix membranes composed of Matrimid® and mesoporous ZSM-5 nanoparticles," J. Memb. Sci., vol. 325, no. 1, pp. 28-39, 2008.

[4] H. I. Lee, H. J. Park, Y. K. Park, J. Y. Hur, J. K. Jeon, and J. M. Kim, "Synthesis of highly stable mesoporous aluminosilicates from commercially available zeolites and their application to the pyrolysis of woody biomass," Catal. Today, vol. 132 , no. $1-4$, pp. 68 74, 2008

[5] S. Suyanta and A. Kuncaka, "Utilization of Rice Husk As Raw Material in Synthesis of Mesoporous Silicates Mcm-41," Indones. J. Chem., vol. 11, no. 3, pp. 279-284, 2011.

[6] I. B. Ugheoke and O. Mamat, "A critical assessment and new research directions of rice husk," JMaejo Int. J. Sci. Technol., vol. 6, no. 03, pp. 430448, 2012.

[7] H. D. Utomo, R. Y. N. Phoon, Z. Shen, L. H. Ng, and Z. B. Lim, "Removal of Methylene Blue Using Chemically Modified Sugarcane Bagasse," Nat.
Resour., vol. 06, no. 04, pp. 209-220, 2015.

[8] D. Govindarajan and G. Jayalakshmi, "XRD, FTIR and Microstructure Studies of Calcined Sugarcane Bagasse Ash," Adv. Appl. Sci. Res., vol. 2, no. 3, pp. 544-549, 2011.

[9] P. Worathanakul, W. Payubnop, and A. Muangpet, "Characterization for Posttreatment Effect of Bagasse Ash for Silica Extraction,” Int. J. Chem. Mol. Nucl. Mater. Metall. Eng., vol. 3, no. 8, pp. 339-341, 2009.

[10] I. R. Shaikh and A. A. Shaikh, "Utilization of Wheat Husk Ash as Silica Source for the Synthesis of MCM-41 Type Mesoporous Silicates: A Sustainable Approach towards Valorization of the Agricultural Waste Stream," Res. J. Chem. Sci. Res. J. Chem. Sci, vol. 3, no. 11, pp. 2231606, 2013.

[11] D. M. Ibrahim, S. A. El-Hemaly, and F. M. Abdel-Kerim, "Study of rice-husk ash silica by infrared spectroscopy," Thermochim. Acta, vol. 37, no. 3, pp. 307-314, 1980.

[12] M. M. Mohamed, F. I. Zidan, and M. Thabet, "Synthesis of ZSM-5 zeolite from rice husk ash: Characterization and implications for photocatalytic 
degradation catalysts," Microporous Mesoporous Mater., vol. 108, no. 1-3, pp. 193-203, 2008.

[13] M. P. Moisés, C. T. P. Da Silva, J. G. Meneguin, E. M. Girotto, and E. Radovanovic, "Synthesis of zeolite $\mathrm{NaA}$ from sugarcane bagasse ash," Mater. Lett., vol. 108, pp. 243-246, 2013.

[14] J. Haber, J. H. Block, and B. Delmon, "Manual of methods and procedures for catalyst characterization (Technical Report)," Pure Appl. Chem., vol. 67, no. 8-9, pp. 1257-1306, 2007.

[15] R. Haul, "S. J. Gregg, K. S. W. Sing: Adsorption, Surface Area and
Porosity," Berichte der Bunsengesellschaft für physikalische Chemie, vol. 86, no. 10. pp. 957-957, 1982.

[16] A. W. Adamson and A. P. Gast, "Physical Chemistry of Surfaces", John Wiley \& Sons, Inc, New York, 1997.

[17] J. Choi, J. Kim, K. S. Yoo, and T. G. Lee, "Synthesis of mesoporous $\mathrm{TiO} 2 / \gamma$ $\mathrm{Al} 2 \mathrm{O} 3$ composite granules with different sol composition and calcination temperature," Powder Technol., vol. 181, no. 1, pp. 83-88, 2008. 